\title{
Focusing On A Unique Innate Memory Cell Population Of Natural Killer Cells In The Fight Against COVID-19: Harnessing The Ubiquity Of Cytomegalovirus Exposure
}

Keywords: COVID-19, SARS-CoV-2, NK cells, NKG2C, NKG2A, Influenza, Immunotherapy.

Citation: Jaiswal S.R., Malhotra P., Mitra D.K., Chakrabarti S.. Focusing on a unique innate memory cell population of natural killer cells in the fight against COVID-19: harnessing the ubiquity of cytomegalovirus exposure. Mediterr J Hematol Infect Dis 2020, 12(1): e2020047, DOI: http://dx.doi.org/10.4084/MJHID.2020.047

This is an Open Access article distributed under the terms of the Creative Commons Attribution License (https://creativecommons.org/licenses/by-nc/4.0), which permits unrestricted use, distribution, and reproduction in any medium, provided the original work is properly cited.

Introduction. The current pandemic of severe acute respiratory syndrome coronavirus 2 (SARS-CoV-2) manifesting as severe pneumonia in a subgroup of patients ${ }^{1,2}$ has generated interest in the immunological response to this virus or the lack of it. ${ }^{3}$ Despite being a novel virus, many of the patients are either asymptomatic or mildly symptomatic. ${ }^{4}$ On the other hand, a subgroup of patients demonstrates a severe cytokine storm, similar to that witnessed in the macrophage activation syndrome (MAS) or hemophagocytic syndrome (HPS) ${ }^{5}$ This response begs the question if there exists innate protection against this new pathogen and, if so, what that might be.

NKG2C+ Natural Killer Cells: Innate Memory Cells and Cytomegalovirus. Natural Killer (NK) cells are the frontline warriors in the launch of antiviral immunity. However, these cells act in an antigenindependent manner and last for a short while, a characteristic of the innate immune response. In mice, it was observed that NK cells bearing Ly49H receptors were preferentially expanded in response to cytomegalovirus (CMV) infection, the viral protein m157 being the trigger. ${ }^{6}$ More importantly, these cells persisted and expanded in response to re-challenge with the virus, mimicking a memory response akin to the adaptive immune counterpart. A similar subtype was identified in humans with the expansion of NK cells expressing a $\mathrm{C}$ lectin type receptor $\mathrm{NKG} 2 \mathrm{C}$, when cultured with CMV infected fibroblasts. ${ }^{7}$ This subtype was further characterized by the absence of the corresponding inhibitory receptor NKG2A, a high expression of CD57 receptor (a marker of maturation), an amplified antibody-dependent cellular cytotoxicity through the CD16 receptor and a strong interferongamma (IFN $\gamma$ ) response. While conventional effector NK cells are short-lasting, these cells were found to last for years in CMV seropositive individuals, but not in those who are CMV naïve. ${ }^{8}$ Thus, the NKG2C subset of NK cells was identified as a unique subgroup of innate cells with a memory phenotype generated by CMV infection. However, these cells were found to expand in response against several RNA viruses as well.

Hypothesis. Our group has been working on this memory subset of NK cells following haploidentical hematopoietic cell transplantation (HCT) with a novel approach of $\mathrm{T}$ cell costimulation blockade with CTLA4Ig. High NKG2C+ NK cell levels were observed to be protective against the recurrence of CMV reactivation, as well as reactivation of adenovirus in this protocol. ${ }^{9,10}$ In addition, NKG2C+ NK cells inversely correlated with graft-versus-host disease (GVHD) following haploidentical HCT in our study, ${ }^{11}$ confirming similar findings reported by others as well. ${ }^{12}$ This has led us to speculate whether these cells may be protective against the SARS-CoV-2 infection as well. If so, the possibility of these cells being isolated and expanded from haploidentical family donors and used for adoptive immunotherapy against COVID-19 is worth consideration. The following sections discuss the rationale for this proposition and its possible implications.

NKG2C+NK Cells In Other Viral Infections. This subset of NK cells with NKG2C expression has also been found to rapidly expand following influenza vaccination with increased IFN $\gamma$ release..$^{13}$ Prolonged memory response to influenza strains is uncommon and annual vaccination is recommended. In a subgroup of 21 HCT recipients prospectively evaluated by us during a seasonal outbreak in 2019, 8 developed H1N1 infection. ${ }^{14}$ All eight patients had high NKG2C+NK cell levels $(22.1 \pm 9.5 \%)$, with a substantial increase in these cells four weeks following the infection $(41.8 \pm$ 
13.3\%). All patients had mild to moderate symptoms with none developing lower respiratory infections, suggesting a possible role of expanded NKG2C+NK cells in retarding the progression of $\mathrm{H} 1 \mathrm{~N} 1$ infection. A similar expansion of $\mathrm{NKG} 2 \mathrm{C}+\mathrm{NK}$ cells has been reported following Hantavirus infections, who were CMV seropositive. ${ }^{15}$ This subset of NK cells was also associated with a lower viral load in those with HIV infections. ${ }^{16}$ These observations suggest that while CMV infection is essential for the development of the NKG2C subset of the NK cell population, this population may also functionally expand in response to a wide array of viruses. The response against both DNA and RNA viruses in an antigen-independent manner, in terms of further expansion, sets these NK cells apart from memory cells of adaptive lineage, which are highly antigen-specific in their response.$^{17} \mathrm{~A}$ similar memory response of NK cells has been demonstrated against mycobacterium in mouse models. ${ }^{18}$ In patients with latent infection with mycobacterium tuberculosis, vaccination with Bacillus Calmette-Guérin (BCG) induced a long term NK cell response lasting for 12 months. ${ }^{19}$

\section{Can NKG2C+NK Cells Provide Protective Immunity Against COVID-19? Studies on} immunological predispositions and their consequences, concerning coronavirus disease 2019 (COVID-19), are still scant. However, a study from China has shown an increase in the expression of NKG2A receptors in NK cells following SARS-CoV-2 infection and a corresponding decrease in this inhibitory receptor following recovery. ${ }^{20}$ Even though the report does not allude to the NKG2C+ NK cell subset, it is worth noting that the expression of NKG2A inversely correlated with $\mathrm{NKG} 2 \mathrm{C}$, as shown by our group and also by others. ${ }^{21}$ HLA E is a ligand for both NKG2A as well as NKG2C receptors, with the former binding its ligand with a higher affinity. ${ }^{22}$ Thus, the absence of NKG2A expression is a pre-requisite for the binding of $\mathrm{NKG} 2 \mathrm{C}$ to the putative receptors and further cytotoxicity. Virus infections often upregulate HLA-E expression on the infected cells, preventing its killing by NK cells expressing NKG2A, despite having the full repertoire of cytotoxic receptors. ${ }^{23}$ Thus, a higher proportion of NKG2A-NKG2C+NK cells might offer better protection against such infections. In addition, the correlation between high expression of NKG2A and an adverse outcome in those with COVID-19 has prompted researchers to speculate if monoclonal antibodies against NKG2A such as Monalizumab may potentially reverse the inhibition of the innate immune system induced by the virus. ${ }^{24,25}$

Furthermore, in-vitro studies have shown that signaling via specific Notch ligands in cord progenitor cells, such as Jagged2, Delta1, or Delta4, may result in the expansion of an immature phenotype of NK cells without NKG2A expression. ${ }^{26}$ These NKG2A-KIRCD56bright NK cells were shown to upregulate receptors such as NKp44, NKp30, and DNAM-1. This does not conform to the natural stages of maturation of NK cells in-vivo and rather reflects an accelerated functional ability despite an immature phenotype, characterized by augmented release of IFN $\gamma$ and cytotoxicity against the K562 cell line- a functional phenotype resembling NKG2A-NKG2C + NK cells. If developed clinically, this might represent a novel way of harnessing functional NK cells from cord blood, enabling the genesis of an off the shelf product for antiviral as well as anticancer immunotherapy.

Harnessing Antigen-Independent Properties of Innate Memory Cells in COVID-19. In the earlier widespread coronavirus infections as in SARS-CoV-1, a lack of cytotoxic NK cells was strongly correlated with the severity of the disease. ${ }^{27}$ This has drawn attention to the possible use of NK cell-based immunotherapy in COVID-19. Derived from the above findings, we hypothesize that this unique group of innate immune cells may have a specific protective role in COVID-19. Given the large number of patients infected with this virus across the globe, a study of the role of $\mathrm{NKG} 2 \mathrm{C}+\mathrm{NK}$ cells becomes both pertinent and urgent, as these cells may be boosted by influenza vaccination as well as $\mathrm{BCG}^{28-30}$ and can be generated ex-vivo for adoptive immunotherapy from CMV seropositive donors, as prior CMV infection is a prerequisite for the generation and expansion of this unique population of NK cells with a memory phenotype ${ }^{31}$ Furthermore, the fatal HPS often found in fatal cases of COVID- $19,{ }^{5}$ is an end-result of abortive NK cell cytotoxicity, lending further credence to the hypothesis that cytotoxic NK cells and the NKG2C subset, in particular, may protect against severe disease in patients infected with COVID-19. Our early results on the use of heat-killed Mycobacterium w (Mw) in patients diagnosed with Covid-19 infection are encouraging. ${ }^{32}$

If that be the case, an early immunological intervention might reduce disease severity as well as mortality. We have proposed a similar study to evaluate the NK cell subsets in those exposed to SARS-CoV2 and those developing the disease in India as CMV seropositivity is ubiquitous in the population. ${ }^{33}$ The fact that NKG2A-NKG2C + NK cells have been found to be protective against GVHD in haploidentical HCT, despite having a potent antiviral and antitumor activity, is encouraging. ${ }^{11,12}$ If found to be protective, this may indicate an opportunity to intervene and boost this subset through either vaccination or adoptive immunotherapy from family donors. 


\section{Sarita Rani Jaiswal $^{1,2}$, Pankaj Malhotra ${ }^{3}$, Dipendra K Mitra ${ }^{4}$ and Suparno Chakrabarti ${ }^{1,2}$. \\ ${ }^{1}$ Cellular Therapy and Immunology, Manashi Chakrabarti Foundation. \\ ${ }^{2}$ Department of Blood and Marrow Transplantation Dharamshila Narayana Super-speciality Hospital, New Delhi, India. \\ ${ }^{3}$ Clinical Hematology, Department of Internal Medicine, Post-Graduate Institute of Medical Education and Research, Chandigarh, India. \\ ${ }^{4}$ Department of Immunology, All India Institute of Medical Sciences, New Delhi, India.}

Competing interests: The authors declare no conflict of Interest.

Correspondence to: Suparno Chakrabarti, Cellular Therapy and Immunology, Manashi Chakrabarti Foundation, Department of Blood and Marrow Transplantation \& Hematology, Dharamshila Narayana Super-specialty Hospital and Research Centre Vasundhara Enclave, New Delhi-110096, India. Email: foundationforcure@gmail.com

\section{References:}

1. Zhu N Zhang D, Wang W, Li X, Yang B, Song J, Zhao X, Huang B, Shi W, Lu R et al: A Novel Coronavirus from Patients with Pneumonia in China, 2019. N Engl J Med 2020, 382(8):727-733. https://doi.org/10.1056/NEJMoa2001017 PMid:31978945 PMCid:PMC7092803

2. Guan WJ, Ni ZY, Hu Y, Liang WH, Ou CQ, He JX, Liu L, Shan H, Lei CL, Hui DSC et al: Clinical Characteristics of Coronavirus Disease 2019 in China. N Engl J Med 2020. https://doi.org/10.1101/2020.02.06.20020974

3. Chen G, Wu D, Guo W, Cao Y, Huang D, Wang H, Wang T, Zhang X, Chen H, Yu H et al: Clinical and immunologic features in severe and moderate Coronavirus Disease 2019. J Clin Invest 2020 .

https://doi.org/10.1101/2020.02.16.20023903

4. Tian S, Hu N, Lou J, Chen K, Kang X, Xiang Z, Chen H, Wang D, Liu N, Liu D et al: Characteristics of COVID-19 infection in Beijing. J Infect 2020, 80(4):401-406.

https://doi.org/10.1016/j.jinf.2020.02.018

PMid:32112886 PMCid:PMC7102527

5. Zhang C, Wu Z, Li JW, Zhao H, Wang GQ: The cytokine release syndrome (CRS) of severe COVID-19 and Interleukin-6 receptor (IL-6R) antagonist Tocilizumab may be the key to reduce the mortality. Int J Antimicrob Agents 2020:105954. https://doi.org/10.1016/j.ijantimicag.2020.105954 PMid:32234467 PMCid:PMC7118634

6. Sun JC, Beilke JN, Lanier LL: Adaptive immune features of natural killer cells. Nature 2009, 457(7229):557-561.

https://doi.org/10.1038/nature07665

PMid:19136945 PMCid:PMC2674434

7. Guma M, Budt M, Saez A, Brckalo T, Hengel H, Angulo A, Lopez-Botet M: Expansion of CD94/NKG2C+ NK cells in response to human cytomegalovirus-infected fibroblasts. Blood 2006, 107(9):3624-3631. https://doi.org/10.1182/blood-2005-09-3682 PMid:16384928

8. Foley B, Cooley S, Verneris MR, Pitt M, Curtsinger J, Luo X, Lopez-Verges S, Lanier LL, Weisdorf D, Miller JS: Cytomegalovirus reactivation after allogeneic transplantation promotes a lasting increase in educated NKG2C+ natural killer cells with potent function. Blood 2012, 119(11):2665-2674.

https://doi.org/10.1182/blood-2011-10-386995 PMid:22180440 PMCid:PMC3311280

9. Jaiswal SR, Bhakuni P, Bhagawati G, Chakrabarti A, Chakrabarti $\mathrm{S}$ : CTLA4Ig-based T-cell costimulation blockade is associated with reduction of adenovirus viremia following posttransplantation cyclophosphamide-based haploidentical transplantation. Bone Marrow Transplant 2019. https://doi.org/10.1038/s41409-019-0549-6 PMid:31089272

10. Jaiswal SR, Bhakuni P, Joy A, Kaushal S, Sudhish D, Aiyer HM, Chakrabarti S: Early Expansion of CD56dimNKG2Alow with Late Surge and Persistence of CD56dimNKG2AnegNKG2Cbright NK Cells Attenuate Cytomegalovirus (CMV) Replication and Recurrence As Well As Leukemia Relapse Following
Haploidentical HSCT with T Cell Costimulation Blockade and PTCy. Biology of Blood and Marrow Transplantation 2019, 25(3):S328.

https://doi.org/10.1016/j.bbmt.2018.12.529

11. Jaiswal SR, Bhakuni P, Bhagwati G, Aiyar HM, Chakrabarti A, Chakrabarti S: Alterations in NKG2A and NKG2C Subsets of Natural Killer Cells Following Epstein-Barr Virus Reactivation in CTLA4Ig-based Haploidentical Transplantation Is Associated With Increased Chronic Graft-Versus-Host Disease. Transplantation 2020, 104(1):e23-e30.

https://doi.org/10.1097/TP.0000000000002941 PMid:31478993

12. Kordelas L, Steckel NK, Horn PA, Beelen DW, Rebmann V: The Activating NKG2C Receptor Is Significantly Reduced in NK Cells after Allogeneic Stem Cell Transplantation in Patients with Severe Graft-versus-Host Disease. Int J Mol Sci 2016, 17(11). https://doi.org/10.3390/ijms17111797 PMid:27801784 PMCid:PMC5133798

13. Goodier MR, Rodriguez-Galan A, Lusa C, Nielsen CM, Darboe A, Moldoveanu AL, White MJ, Behrens R, Riley EM: Influenza Vaccination Generates Cytokine-Induced Memory-like NK Cells: Impact of Human Cytomegalovirus Infection. J Immunol 2016, 197(1):313-325.

https://doi.org/10.4049/jimmunol.1502049 PMid:27233958 PMCid:PMC4911617

14. Jaiswal SR, Bhagwati G, Soni M, Thatai A, Aiyer H, Chakrabarti S: Prophylactic Oseltamivir During Major Seasonal Influenza H1N1 Outbreak Might Reduce Both H1N1 And Associated Pulmonary Aspergillosis In Children Undergoing Haploidentical Transplantation. Transpl Infect Dis 2020:e13309.

https://doi.org/10.1111/tid.13309 PMid:32383345

15. Bjorkstrom NK, Lindgren T, Stoltz M, Fauriat C, Braun M, Evander M, Michaelsson J, Malmberg KJ, Klingstrom J, Ahlm C et al: Rapid expansion and long-term persistence of elevated NK cell numbers in humans infected with hantavirus. J Exp Med 2011, 208(1):13-21.

https://doi.org/10.1084/jem.20100762

PMid:21173105 PMCid:PMC3023129

16. Gondois-Rey F, Cheret A, Granjeaud S, Mallet F, Bidaut G, Lecuroux C, Ploquin M, Muller-Trutwin M, Rouzioux C, Avettand-Fenoel $\mathrm{V}$ et al: $\mathrm{NKG} 2 \mathrm{C}(+)$ memory-like $\mathrm{NK}$ cells contribute to the control of HIV viremia during primary infection: Optiprim-ANRS 147. Clin Transl Immunology 2017, 6(7):e150. https://doi.org/10.1038/cti.2017.22 PMid:28791125 PMCid:PMC5539415

17. Geary CD, Sun JC: Memory responses of natural killer cells. Semin Immunol 2017, 31:11-19. https://doi.org/10.1016/j.smim.2017.08.012 PMid:28863960

18. Venkatasubramanian S, Cheekatla S, Paidipally P, Tripathi D, Welch E, Tvinnereim AR, Nurieva R, Vankayalapati R: IL-21dependent expansion of memory-like NK cells enhances protective immune responses against Mycobacterium tuberculosis. Mucosal 
Immunol 2017, 10(4):1031-1042.

https://doi.org/10.1038/mi.2016.105

PMid:27924822 PMCid:PMC5462891

19. Suliman S, Geldenhuys H, Johnson JL, Hughes JE, Smit E, Murphy M, Toefy A, Lerumo L, Hopley C, Pienaar B et al: Bacillus Calmette-Guerin (BCG) Revaccination of Adults with Latent Mycobacterium tuberculosis Infection Induces Long-Lived BCG-Reactive NK Cell Responses. J Immunol 2016, 197(4):11001110

https://doi.org/10.4049/jimmunol.1501996

PMid:27412415 PMCid:PMC4976036

20. Zheng M, Gao Y, Wang G, Song G, Liu S, Sun D, Xu Y, Tian Z Functional exhaustion of antiviral lymphocytes in COVID-19 patients. Cell Mol Immunol 2020.

https://doi.org/10.1038/s41423-020-0402-2

PMid:32203188 PMCid:PMC7091858

21. Jaiswal SR, Bhakuni P, Bhagwati G, Aiyar HM, Chakrabarti A, Chakrabarti S: Alterations In NKG2A and NKG2C Subsets Of Natural Killer Cells following Epstein Barr Virus Reactivation In CTLA4Ig Based Haploidentical Transplantation Is Associated With Increased Chronic Graft-Versus-Host Disease Transplantation 2019. https://doi.org/10.1097/TP.0000000000002941 PMid:31478993

22. Vales-Gomez M, Reyburn HT, Erskine RA, Lopez-Botet M, Strominger JL: Kinetics and peptide dependency of the binding of the inhibitory $\mathrm{NK}$ receptor $\mathrm{CD} 94 / \mathrm{NKG} 2-\mathrm{A}$ and the activating receptor CD94/NKG2-C to HLA-E. EMBO J 1999, 18(15):42504260

https://doi.org/10.1093/emboj/18.15.4250 PMid:10428963 PMCid:PMC1171501

23. Nattermann J, Nischalke HD, Hofmeister V, Kupfer B, Ahlenstiel G, Feldmann G, Rockstroh J, Weiss EH, Sauerbruch T, Spengler U: HIV-1 infection leads to increased HLA-E expression resulting in impaired function of natural killer cells. Antivir Ther 2005, 10(1):95-107.

24. Yaqinuddin A, Kashir J: Innate immunity in COVID-19 patients mediated by NKG2A receptors, and potential treatment using Monalizumab, Cholroquine, and antiviral agents. Medical Hypotheses 2020, 140:109777. https://doi.org/10.1016/j.mehy.2020.109777 PMid:32344314 PMCid:PMC7194824

25. Antonioli L, Fornai M, Pellegrini C, Blandizzi C: NKG2A and COVID-19: another brick in the wall. Cellular \& Molecular Immunology 2020. https://doi.org/10.1038/s41423-020-0450-7

PMid:32382127 PMCid:PMC7203720

26. Beck RC, Padival M, Yeh D, Ralston J, Cooke KR, Lowe JB: The Notch Ligands Jagged2, Delta1, and Delta4 Induce Differentiation and Expansion of Functional Human NK Cells from CD34+ Cord Blood Hematopoietic Progenitor Cells. Biology of Blood and Marrow Transplantation 2009, 15(9):1026-1037. https://doi.org/10.1016/j.bbmt.2009.06.002 PMCid:PMC2730186

27. The involvement of natural killer cells in the pathogenesis of severe acute respiratory syndrome. Am J Clin Pathol 2004, 121(4):507-511.

https://doi.org/10.1309/WPK7Y2XKNF4CBF3R PMid:15080302 PMCid:PMC7110090

28. Dou Y, Fu B, Sun R, Li W, Hu W, Tian Z, Wei H: Influenza vaccine induces intracellular immune memory of human NK cells. PLoS One 2015, 10(3): e0121258. https://doi.org/10.1371/journal.pone.0121258 PMid:25781472 PMCid:PMC4363902

29. Wagstaffe HR, Mooney JP, Riley EM, Goodier MR: Vaccinating for natural killer cell effector functions. Clin Transl Immunology 2018, 7(1):e1010. https://doi.org/10.1002/cti2.1010 PMid:29484187 PMCid:PMC5822400

30. Kleinnijenhuis J, Quintin J, Preijers F, Joosten LA, Jacobs C, Xavier RJ, van der Meer JW, van Crevel R, Netea MG: BCGinduced trained immunity in NK cells: Role for non-specific protection to infection. Clin Immunol 2014, 155(2):213-219. https://doi.org/10.1016/j.clim.2014.10.005 PMid:25451159 PMCid:PMC5084088

31. Romee R, Rosario M, Berrien-Elliott MM, Wagner JA, Jewell BA, Schappe T, Leong JW, Abdel-Latif S, Schneider SE, Willey S et al: Cytokine-induced memory-like natural killer cells exhibit enhanced responses against myeloid leukemia. Sci Transl Med 2016, 8(357):357ra123. https://doi.org/10.1126/scitranslmed.aaf2341 PMid:27655849 PMCid:PMC5436500

32. Sehgal I, Bhalla A, Puri G, Yaddanapudi L, Singh M, Malhotra P, Dhooria S, Suri V, Agarwal R: Safety of an immunomodulator Mycobacterium W in COVID-19. Lung India 2020, 37(3):279-281. https://doi.org/10.4103/lungindia.lungindia_242_20 PMid: 32367857

33. Chakravarti A, Kashyap B, Matlani M: Cytomegalovirus infection: An Indian perspective. Indian Journal of Medical Microbiology 2009, 27(1):3-11. 